\title{
PREPARASI, MODIFIKASI DAN KARAKTERISASI KATALIS BIFUNGSIONAL Sn-H-ZEOLIT ALAM MALANG
}

\author{
Nur Okta Erlina, Suci Amalia, Susi Nurul K \\ Jurusan Kimia, Fakultas Sains dan Teknologi UIN Maulana Malik Ibrahim Malang
}

\begin{abstract}
ABSTRAK
Telah dilakukan preparasi, modifikasi dan karakterisasi katalis Sn-H-Zeolit alam Malang. Zeolit alam diaktivasi dengan menggunakan larutan asam $\mathrm{NH}_{4} \mathrm{NO}_{3} 2 \mathrm{M}$ sehingga dihasilkan H-Zeolit. Logam Sn diimpregnasikan pada sampel $\mathrm{H}$-Zeolit menggunakan variasi konsentrasi $\mathrm{SnCl}_{2} \cdot 2 \mathrm{H}_{2} \mathrm{O} 0,12$ : 0,24 dan 0,48 $\mathrm{M}$. Metode yang digunakan adalah proses hidrotermal menggunakan suhu $90{ }^{\circ} \mathrm{C}$ selama 12 jam, kemudian dikalsinasi pada suhu $500{ }^{\circ} \mathrm{C}$ selama 4 jam. Karakterisasi katalis meliputi morfologi permukaan katalis menggunakan SEM-EDAX, analisis kesaman menggunakan adsorpsi ammonia, luas permukaan spesifik katalis menggunakan BET (NOVA-1200) serta kristalinitas katalis menggunakan XRD.

Hasil penelitian menunjukkan bahwa distribusi logam terbaik pada pengemban zeolit adalah pada penggunaan konsentrasi logam $\mathrm{SnCl}_{2} \cdot 2 \mathrm{H}_{2} \mathrm{O} \quad 0,24 \mathrm{M}$. Nilai keasaman dari hasil variasi terbaik adalah 0,4682 $\mathrm{mmol} / \mathrm{g}$, sedangkan luas permukaan spesifiknya adalah sebesar 2,268 $\mathrm{m}^{2} / \mathrm{g}$. Dari hasil karakterisasi XRD dapat diketahui bahwa proses modifikasi pada zeolit tidak menyebabkan perubahan struktur dan kristalinitas katalis.
\end{abstract}

Kata kunci: Zeolit alam, Impregnasi, logam $\mathrm{SnCl}_{2} \cdot 2 \mathrm{H}_{2} \mathrm{O}$

\section{PENDAHULUAN}

Indonesia merupakan negara yang memiliki potensi zeolit alam dalam jumlah yang cukup besar dan tersebar di 46 lokasi, antara lain di Lampung, Jawa Barat, Jawa Tengah, dan Jawa Timur. Ditinjau dari nilai Kapasitas Tukar Kation (KTK), kualitas zeolit alam Indonesia tergolong baik. Namun, potensi yang besar ini belum dimanfaatkan secara optimal dan baru terbatas untuk mengolah limbah industri, suplemen pada makanan ternak dan pupuk (Laniwati, 1999).

Zeolit alam terdiri atas gugus alumina oksida dan gugus silika oksida yang masing-masing berbentuk tetrahedral dan saling dihubungkan oleh atom oksigen sedemikian rupa sehingga membentuk kerangka tiga dimensi. Sifat yang dimiliki oleh zeolit dimungkinkan untuk dimodifikasi menjadi katalis, adsorben, penukar ion, maupun sebagai pengemban logam aktif (Muliasari, 2006).

Salah satu keberadaan zeolit alam adalah di daerah Malang Selatan. Zeolit alam asal Malang banyak mengandung mineral jenis mordenit 55 - $85 \%$ (Laniwati, 1999) dan memiliki kristalinitas mordenit 38 - $39 \%$ (Savitri dan Veronica, 2010).
Setiadi dan Astri (2007) juga melaporkan hasil karakterisasi zeolit alam Malang dengan kandungan mordenit yang relatif tinggi dan tercampur dengan jenis klinoptilolit serta beberapa senyawa pengotor lainnya.

Zeolit dapat dimanfaatkan sebagai katalis karena memiliki struktur kerangka tiga dimensi dengan rongga di dalamnya dan luas permukaan yang besar. Upaya yang dilakukan untuk memaksimalkan kerja dari zeolit sebagai katalis yakni dengan aktivasi dan modifikasi. Modifikasi dilakukan dengan cara mendispersikan komponen aktif pada pengemban zeolit (Triyono, 1994). Banyak cara yang dapat digunakan untuk mendispersikan logam aktif ke dalam pengemban. Cara yang paling umum adalah impregnasi, yaitu dengan memasukkan katalis logam secara paksa ke dalam rongga-rongga pengemban, pertukaran ion, kopresipitasi, dan deposisi (Anderson, 1981).

Pendispersian komponen aktif pada zeolit merupakan salah satu alternatif untuk memperbaiki kinerja dan mengatasi kelemahan katalis logam murni. Kelemahan katalis logam murni antara lain memiliki stabilitas termal rendah, mudah mengalami 
penurunan luas permukaan akibat pemanasan dan mudah terjadi penggumpalan serta tingginya harga dan biaya pemakaian logam murni sebagai katalis. Pemakaian pengemban akan memberikan dasar yang stabil sehingga dapat memperpanjang waktu pakai katalis (Sadiana, 2001). Selain itu, menurut Sriatun dan Suhartana (2002) logam yang diembankan pada padatan zeolit melalui impregnasi akan menjadikan logam dalam zeolit sebagai katalis bersifat bifungsional.

Hasil penelitian sebelumnya, Cardenas, dkk., (2002) telah mensintesis katalis menggunakan logam $\mathrm{Sn}$ dan $\mathrm{Pd}$ yang diembankan pada $\mathrm{SiO}_{2}$ dan $\mathrm{Al}_{2} \mathrm{O}_{3}$ dengan berbagai pelarut. Moliner, dkk., (2010) juga telah mensintesis Sn-Beta dan Sn-MCM 41 yang digunakan untuk proses isomerisasi glukosa menjadi fruktosa. Hasil penelitian menunjukkan bahwa katalis SnBeta memiliki aktivitas katalitik sebesar 80 $\%$ dengan selektivitas $30 \%$, sedangkan katalis Sn-MCM 41 memiliki aktivitas katalitik sebesar $31 \%$ serta selektivitas sebesar $41 \%$.

Mengacu pada penelitian di atas, maka pada penelitian ini akan dilakukan impregnasi logam yang diembankan pada padatan zeolit sehingga dihasilkan katalis bifungsional. Zeolit yang digunakan adalah zeolit alam yang berasal dari daerah Turen Malang Selatan, sedangkan logam yang diimpregnasikan adalah $\mathrm{Sn}$ mengingat $\mathrm{Sn}$ mampu digunakan sebagai katalis aktif dalam reaksi isomerisasi glukosa menjadi fruktosa. Selanjutnya akan dipelajari pengaruh pengembanan logam terhadap morfologi, keasaman, luas permukaan serta kristalinitas katalis.

Dengan metode preparasi dan modifikasi katalis berbasis zeolit alam Malang, diharapkan dapat dihasilkan katalis bifungsional yang memiliki karakter yang baik (keasaman dan kristalinitas yang tepat) dan selektif untuk digunakan sebagai katalis aktif pada proses isomerisasi glukosa menjadi fruktosa

\section{METODE PENELITIAN Preparasi Sampel}

Zeolit alam sebanyak 250 gram direndam dalam $500 \mathrm{ml}$ aquades sambil diaduk dengan pengaduk magnet selama sehari semalam pada suhu kamar. Kemudian disaring, endapan yang diperoleh dikeringkan dalam oven pada suhu $100{ }^{\circ} \mathrm{C}$ selama 24 jam.

\section{Aktivasi Zeolit}

Padatan zeolit kering hasil preparasi ditumbuk menjadi serbuk. Ditimbang 50 gram dan ditambahkan dengan larutan $\mathrm{NH}_{4} \mathrm{NO}_{3} 2 \mathrm{M}$ sebanyak $100 \mathrm{~mL}$. Kemudian campuran diaduk secara kontinyu selama 2 jam sampai 4 jam tanpa pemanasan. Campuran disaring dan dicuci dengan aquades sampai $\mathrm{pH}$ filtrat netral. Padatan yang diperoleh dipanaskan pada suhu 110 ${ }^{\circ} \mathrm{C}$ dalam oven selama $12 \mathrm{jam}$, sehingga menghasilkan H-zeolit. Kemudian dilakukan uji keasaman zeolit hasil aktivasi.

\section{Modifikasi Sn-H-Zeolit Alam Malang Dengan Metode Impregnasi Dengan Menggunakan Variasi Konsentrasi $\mathrm{SnCl}_{2} .2 \mathrm{H}_{2} \mathrm{O}$}

H-zeolit hasil aktivasi ditimbang masing-masing 10 g sebanyak 3 kali. Kemudian dicampur dengan larutan $\mathrm{SnCl}_{2} .2 \mathrm{H}_{2} \mathrm{O}$ masing-masing $20 \mathrm{~mL}$ dengan konsentrasi 0,12 M, 0,24 M, dan 0,48 M. Campuran diaduk selama 2 jam, kemudian dilakukan proses hidrotermal dengan cara campuran dipanaskan pada suhu $90{ }^{\circ} \mathrm{C}$ dalam oven selama 12 jam. Selanjutnya zeolit hasil hidrotermal didiamkan selama 24 jam. Kemudian dilakukan penyaringan. Endapan hasil penyaringan kemudian dioven dengan suhu $100{ }^{\circ} \mathrm{C}$ selama 2 jam untuk menghilangkan air. Selanjutnya semua sampel zeolit terimpregnasi diaktivasi dengan cara kalsinasi pada suhu $500{ }^{\circ} \mathrm{C}$ selama 4 jam dalam oven. Pada tahap ini akan dihasilkan katalis zeolit bifungsional yaitu Sn-H-zeolit.

\section{Karakterisasi}


1. Analisis Scanning Electron Microscopy-Energy Dispertive Analysis $X$-Ray (SEM-EDAX)

Zeolit alam hasil modifikasi tiap konsentrasi dikarakterisasi dengan SEMEDAX untuk menganalisa topografi permukaan dan untuk menganalisa elemen yang terdapat dalam sampel zeolit terimpregnasi. Sampel dilapisi dengan $\mathrm{Pt}$ dan ditempatkan pada instrumen SEM kemudian dilakukan pengamatan pada rentang perbesaran 5000 sampai dengan 20.000 kali hingga terlihat ukuran dan bentuk partikel zeolit terimpregnasi dengan jelas.

\section{Penentuan Keasaman}

Zeolit hasil aktivasi dan modifikasi tiap konsentrasi ditentukan keasamannya dengan metode gravimetri yaitu dengan cara adsorpsi gas amoniak pada permukaan katalis. Katalis hasil aktivasi dan modifikasi masing-masing dengan berat $0,5 \mathrm{~g}$ diletakkan dalam kaca arloji yang sebelunya telah diketahui beratnya selanjutnya dipanaskan dalam oven pada suhu $120{ }^{\circ} \mathrm{C}$ selama 2 jam. Katalis didinginkan sebentar dalam suhu ruang, kemudian ditimbang lagi untuk mengetahui berat katalis sebenarnya (tanpa air). Kaca arloji yang berisi katalis diletakkan dalam desikator yang di dalamnya telah diletakkan cawan krus yang berisi amoniak dan dibiarkan selama 24 jam. Kaca arloji dikeluarkan dari desikator dan diangin-anginkan selama 4 jam. Katalis ditimbang dan amoniak yang terserap oleh katalis dapat dihitung dengan rumus:

$$
\text { Keasaman }=\frac{W_{\mathrm{NH}_{3}} \times 1000}{B M_{\mathrm{NH}_{3}} \times \text { Wkatalis }}
$$

$(\mathrm{mmol} / \mathrm{g})$

\section{Adsorpsi Nitrogen}

Zeolit modifikasi dari analisis SEM-EDAX yang terbaik yaitu yang menunjukkan distribusi logam merata pada pengemban zeolit akan dianalisis menggunakan instrumen Quantachrome
Corporation (Nova-1200) untuk mengetahui luas permukaan katalis. Sampel sebanyak 0,1 gram diberi perlakuan dengan gas nitrogen dengan laju aliran $30 \mathrm{~cm}^{3} /$ menit pada suhu 300 ${ }^{\circ} \mathrm{C}$ selama 1 jam dan didinginkan untuk adsorpsi dan desorpsi nitrogen pada suhu $77^{\circ} \mathrm{C}$.

\section{Difraksi Sinar-X (XRD)}

Zeolit modifikasi dari analisis SEM-EDAX yang terbaik yaitu yang menunjukkan distribusi logam merata pada pengemban zeolit akan dianalisis menggunakan teknik difraksi sinar-X (XRD) untuk identifikasi fase kristal dan kekristalan katalis dengan radiasi $\mathrm{Cu} \mathrm{K}_{\alpha}$ $(\lambda=1.5406 \AA$ ) pada $40 \mathrm{kV}$ dan $30 \mathrm{~mA}$, $20 \quad 20-50^{\circ}$ dan kecepatan scan 0,02 $\%$ detik.

\section{HASIL DAN PEMBAHASAN}

Scanning Electron Microscopy-Energy Dispertive Analysis $X$-Ray (SEM-EDAX)

1. Scanning Electron Microscopy

Permukaan zeolit modifikasi dapat dilihat menggunakan Scanning Electron Microscopy (SEM). Hal ini bertujuan untuk mengetahui tingkat dispersi logam yang diembankan pada zeolit, dimana katalis yang memiliki tingkat dispersi tinggi akan memiliki kinerja yang lebih baik (Rodiansono, 2009). Sampel yang dianalisis menggunakan SEM-EDAX adalah zeolit modifikasi logam $\mathrm{SnCl}_{2} \cdot 2 \mathrm{H}_{2} \mathrm{O}$ dengan berbagai konsentrasi diantaranya $0,12 \mathrm{M}, 0,24 \mathrm{M}$ dan $0,48 \mathrm{M}$. Morfologi dan topografi permukaan katalis dilihat menggunakan SEM pada perbesaran 5000 dan 20.000 kali.

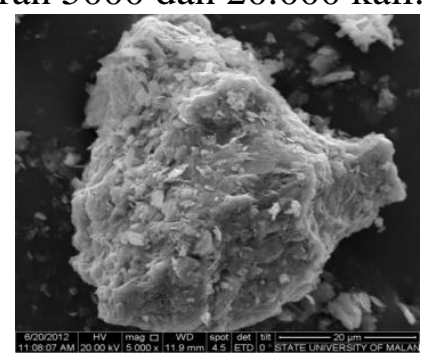

(a) 


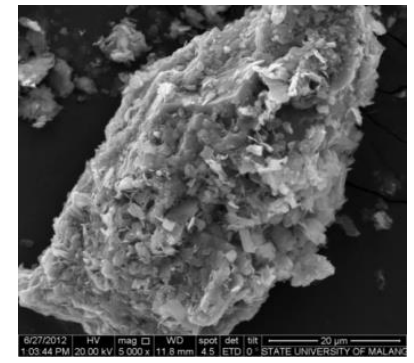

(b)

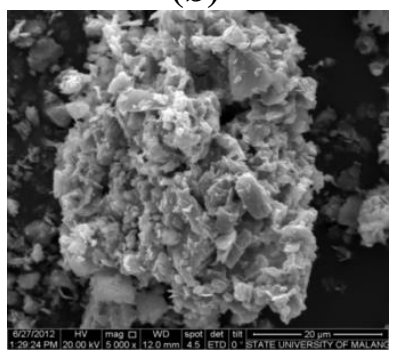

(c)

Gambar 1. Analisis permukaan zeolit modifikasi menggunakan SEM dengan perbesaran 5000 kali (a) konsentrasi $\mathrm{SnCl}_{2} \cdot 2 \mathrm{H}_{2} \mathrm{O} \quad 0,12 \quad \mathrm{M}$ (b) konsentrasi $\mathrm{SnCl}_{2} \cdot 2 \mathrm{H}_{2} \mathrm{O} \quad 0,24 \mathrm{M} \quad$ (c) konsentrasi $\mathrm{SnCl}_{2} \cdot 2 \mathrm{H}_{2} \mathrm{O} 0,48 \mathrm{M}$

Analisis katalis menggunakan SEM perbesaran 5000 kali pada Gambar 1 menunjukkan perbedaan yang signifikan. Adanya titik-titik putih menandakan bahwa logam Sn telah terdistribusi dalam pengemban zeolit. Semakin tinggi konsentrasi logam Sn yang digunakan, maka titik putih yang ada pada pengemban zeolit juga semakin banyak.

Pada Gambar 1 terlihat hasil distribusi logam yang paling baik adalah pada konsentrasi 0,24 M. Pada konsentrasi $0,12 \mathrm{M}$, logam Sn yang ada pada pengemban masih sedikit sehingga tidak bisa memberikan distribusi logam yang maksimal. Pada penggunaan konsentrasi 0,24 M, logam lebih terdistribusi secara merata pada pengemban. Hal ini dapat dilihat dari adanya titik putih yang tersebar merata pada pengemban zeolit. Sedangkan pada konsentrasi 0,48 M logam kurang terdistribusi secara merata pada zeolit. Hal ini ditandai adanya gumpalan putih pada Gambar (c) yang terlihat jelas.
Gumpalan putih yang berkelompok menunjukkan telah terjadinya penumpukan logam terembankan pada permukaan zeolit, artinya tingkat dispersi logam Sn pada permukaan zeolit masih kurang baik.

Hasil analisis zeolit modifikasi menggunakan SEM perbesaran 20000 kali dapat dilihat pada Gambar 2.

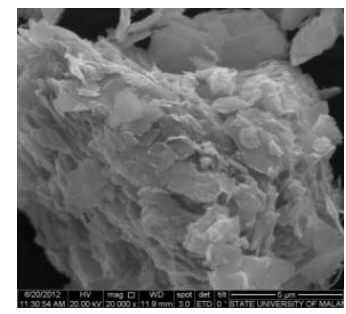

(a)

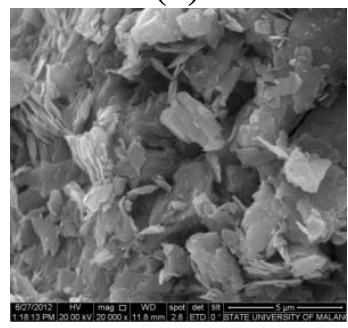

(b)

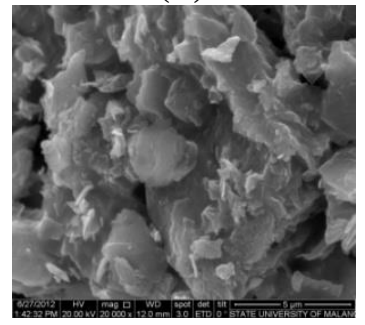

(c)

Gambar 2 Analisis permukaan zeolit modifikasi logam $\mathrm{SnCl}_{2} \cdot 2 \mathrm{H}_{2} \mathrm{O}$ menggunakan SEM dengan perbesaran 20.000 kali (a) konsentrasi $\mathrm{SnCl}_{2} \cdot 2 \mathrm{H}_{2} \mathrm{O}$ $0,12 \mathrm{M}$ (b) konsentrasi 0,24 M (c) konsentrasi 0,48 M.

Pada Gambar 2 analisis menggunakan SEM perbesaran 20000 kali menunjukkan bahwa terdapat gumpalan putih yang menumpuk pada pengembanan logam konsentrasi 0,48 M.

\section{Energy Dispertive Analysis X-Ray}

Analisis menggunakan Energy Dispertive Analysis X-Ray dilakukan untuk mengetahui elemen-elemen penyusun pada sampel yaitu unsur-unsur 
yang ada pada zeolit alam modifikasi variasi konsentrasi logam $\mathrm{Sn}$

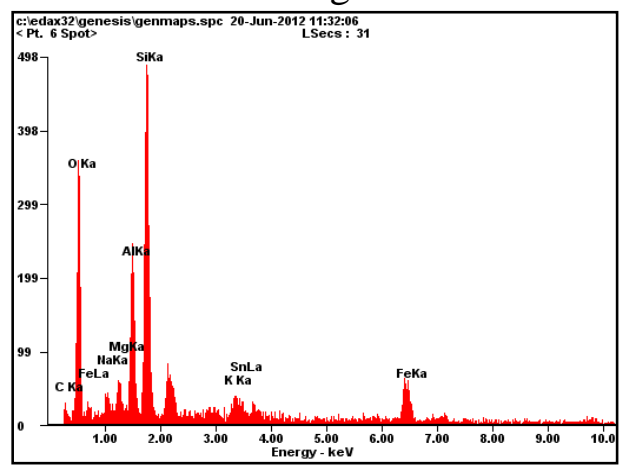

Gambar 3 Difraktogram analisis unsurunsur pada zeolit alam modifikasi $\mathrm{SnCl}_{2} .2 \mathrm{H}_{2} \mathrm{O} 0,12 \mathrm{M}$

Tabel 1 Hasil analisis unsur-unsur zeolit alam modifikasi $\mathrm{SnCl}_{2} .2 \mathrm{H}_{2} \mathrm{O} 0,12 \mathrm{M}$

\begin{tabular}{|c|c|c|}
\hline Elemen & Wt\% & At\% \\
\hline $\mathrm{C}$ & 09,84 & 17,54 \\
\hline $\mathrm{O}$ & 34,44 & 46,07 \\
\hline $\mathrm{Na}$ & 02,39 & 02,23 \\
\hline $\mathrm{Mg}$ & 02,31 & 02,03 \\
\hline $\mathrm{Al}$ & 09,37 & 07,44 \\
\hline $\mathrm{Si}$ & 24,41 & 18,60 \\
\hline $\mathrm{K}$ & 02,15 & 01,18 \\
\hline $\mathrm{Sn}$ & 04,29 & 00,77 \\
\hline $\mathrm{Fe}$ & 10,80 & 04,14 \\
\hline \multicolumn{2}{|c}{}
\end{tabular}

Gambar 4 Difraktogram analisis unsurunsur pada zeolit alam modifikasi $\mathrm{SnCl}_{2} .2 \mathrm{H}_{2} \mathrm{O}$ 0,24 M.

Tabel 2 Hasil analisis unsur-unsur zeolit alam modifikasi $\mathrm{SnCl}_{2} \cdot 2 \mathrm{H}_{2} \mathrm{O} 0,24 \mathrm{M}$

\begin{tabular}{|c|c|c|}
\hline Elemen & $\mathbf{W t \%}$ & $\mathbf{A t \%}$ \\
\hline $\mathrm{C}$ & 09,43 & 16,22 \\
\hline $\mathrm{O}$ & 40,26 & 51,99 \\
\hline $\mathrm{Na}$ & 01,59 & 01,43 \\
\hline $\mathrm{Mg}$ & 01,65 & 01,41 \\
\hline $\mathrm{Al}$ & 09,63 & 07,38 \\
\hline $\mathrm{Si}$ & 22,84 & 16,80 \\
\hline $\mathrm{K}$ & 03,04 & 01,61 \\
\hline $\mathrm{Sn}$ & 05,61 & 00,98 \\
\hline $\mathrm{Fe}$ & 05,95 & 02,20 \\
\hline
\end{tabular}

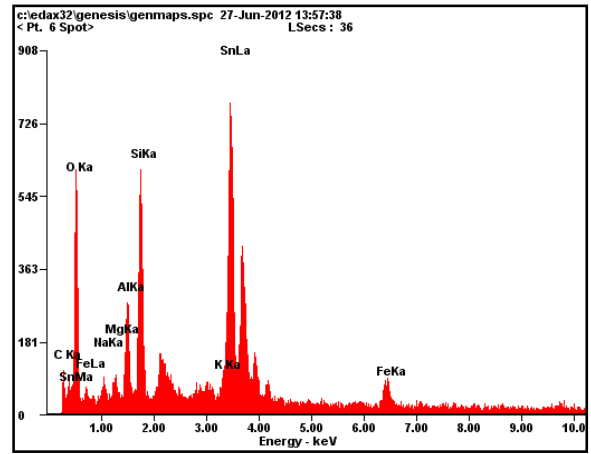

Gambar 5 Difraktogram analisis unsurunsur pada zeolit alam modifikasi $\mathrm{SnCl}_{2} \cdot 2 \mathrm{H}_{2} \mathrm{O} 0,48 \mathrm{M}$

Tabel 3 Hasil analisis unsur-unsur zeolit alam modifikasi $\mathrm{SnCl}_{2} \cdot 2 \mathrm{H}_{2} \mathrm{O} 0,48 \mathrm{M}$

\begin{tabular}{|c|c|c|}
\hline Elemen & Wt\% & At\% \\
\hline $\mathrm{C}$ & 07,70 & 15,77 \\
\hline $\mathrm{O}$ & 33,05 & 50,82 \\
\hline $\mathrm{Na}$ & 01,55 & 01,66 \\
\hline $\mathrm{Mg}$ & 00,97 & 00,98 \\
\hline $\mathrm{Al}$ & 06,36 & 05,80 \\
\hline $\mathrm{Si}$ & 19,21 & 16,82 \\
\hline $\mathrm{K}$ & 01,43 & 00,90 \\
\hline $\mathrm{Sn}$ & 25,11 & 05,20 \\
\hline $\mathrm{Fe}$ & 04,62 & 02,04 \\
\hline
\end{tabular}

Dari data Energy Dispertive Analysis XRay (EDAX) menunjukkan bahwa semakin besar konsentrasi logam $\mathrm{SnCl}_{2} \cdot 2 \mathrm{H}_{2} \mathrm{O}$ yang diimpregnasikan, maka kandungan Sn dalam sampel zeolit juga semakin banyak.

\section{Keasaman Katalis}

Hasil pengujian keasaman dari zeolit alam aktivasi dan modifikasi $\mathrm{SnCl}_{2} \cdot 2 \mathrm{H}_{2} \mathrm{O}$ dapat dilihat pada Tabel 4.

Tabel 4 Keasaman Total Sampel H-Zeolit dan Sn-H-Zeolit

\begin{tabular}{|c|r|c|}
\hline No & Sampel & $\begin{array}{c}\text { Keasaman } \\
\text { Total }(\mathbf{m m o l} / \mathbf{g})\end{array}$ \\
\hline 1. & H-Zeolit & 0,352 \\
\hline 2. & $\begin{array}{r}\text { Sn-H-Zeolit } \\
0,12 \mathrm{M}\end{array}$ & 0,5011 \\
\hline 3. & $\begin{array}{r}\text { Sn-H-Zeolit } \\
0,24 \mathrm{M}\end{array}$ & 0,4682 \\
\hline 4. & $\begin{array}{r}\text { Sn-H-Zeolit } \\
0,48 \mathrm{M}\end{array}$ & 0,4215 \\
& \multicolumn{2}{|c}{} \\
\hline
\end{tabular}


Dari hasil analisis Tabel 4 menunjukkan bahwa keasaman zeolit aktivasi yakni $\mathrm{H}$-zeolit paling kecil diantara zeolit yang telah dimodifikasi dengan logam $\mathrm{SnCl}_{2} \cdot 2 \mathrm{H}_{2} \mathrm{O}$. Pengaruh kalsinasi serta impregnasi telah menyebabkan keasaman dari zeolit meningkat. Akan tetapi semakin besar konsentrasi logam $\mathrm{SnCl}_{2} \cdot 2 \mathrm{H}_{2} \mathrm{O}$ yang diimpregnasikan, maka harga keasaman dari katalis semakin menurun. Hasil keasaman dari zeolit modifikasi yang semakin menurun berhubungan dengan konsentrasi logam yang diembankan pada zeolit. Dimana pada penggunaan konsentrasi logam $\mathrm{SnCl}_{2} \cdot 2 \mathrm{H}_{2} \mathrm{O}$ 0,48 M, logam kurang terdistribusi merata pada permukaan zeolit sehingga nilai keasaman dari katalis Sn-H-zeolit konsentrasi 0,48 $\mathrm{M}$ cenderung paling kecil diantara pengembanan logam konsentrasi 0,12 dan $0,24 \mathrm{M}$.

\section{Adsorpsi Nitrogen}

Analisis dengan metode BET menunjukkan bahwa semakin besar konsentrasi logam yang diimpregnasikan, menghasilkan luas permukaan spesifik yang lebih kecil. Hal ini dapat terlihat pada Tabel5

Tabel 5 Hasil analisis luas permukaan katalis zeolit

\begin{tabular}{|c|c|}
\hline $\begin{array}{c}\text { Konsentrasi } \\
\text { logam Sn }\end{array}$ & $\begin{array}{c}\text { Luas Permukaan } \\
\text { Spesifik }\end{array}$ \\
\hline $0,24 \mathrm{M}$ & $2,268 \mathrm{~m}^{2} / \mathrm{g}$ \\
\hline $0,48 \mathrm{M}$ & $0,946 \mathrm{~m}^{2} / \mathrm{g}$ \\
\hline
\end{tabular}

Pada pengembanan logam $\mathrm{SnCl}_{2} \cdot 2 \mathrm{H}_{2} \mathrm{O} \quad 0,48 \quad \mathrm{M}$ Tabel 4.8 , luas permukaan dari katalis cenderung turun dan lebih kecil dari penggunaaan konsentrasi logam $\mathrm{SnCl}_{2} \cdot 2 \mathrm{H}_{2} \mathrm{O}$ 0,24 M. Hasil analisis luas permukaan ini didukung dengan hasil analisis SEM dan keasaman dari katalis. Dimana dari hasil SEM menunjukkan bahwa penggunaan konsentrasi logam Sn 0,48 menghasilkan distribusi logam yang tidak merata pada pengemban. Selain itu hasil analisis keasaman juga paling kecil diantara penggunaan konsentrasi logam $\mathrm{Sn}$ 0,12 dan 0,24 M.

Pada pengembanan logam menggunakan konsentrasi $\mathrm{SnCl}_{2} \cdot 2 \mathrm{H}_{2} \mathrm{O} 0,48$ $\mathrm{M}$ mengalami distribusi logam $\mathrm{Sn}$ yang tidak merata pada permukaan katalis (terjadi sintering). Hal ini berkaitan dengan fenomena impregnasi dimana konsentrasi logam Sn yang relatif tinggi mengakibatkan kompetisi antara ion satu dengan yang lain pada mulut pori. Akibatnya terjadi akumulasi pada satu tempat dan menutup mulut pori serta saluran pori, sehingga jumlah Sn yang relatif banyak tidak meningkatkan luas permukaan spesifik sampel.

\section{Difraksi Sinar-X (XRD)}

Analisis menggunakan difraksi sinar$\mathrm{X}$ (XRD) dilakukan untuk melihat perubahan yang terjadi pada kristalinitas zeolit alam dan zeolit modifikasi hasil pengembanan logam Sn yang memberikan luas permukaan terbesar. Data difraktogram zeolit alam Malang dan zeolit alam Malang modifikasi logam $\quad \mathrm{SnCl}_{2} \cdot 2 \mathrm{H}_{2} \mathrm{O} \quad 0,24 \quad \mathrm{M}$ ditunjukkan pada Gambar 6.
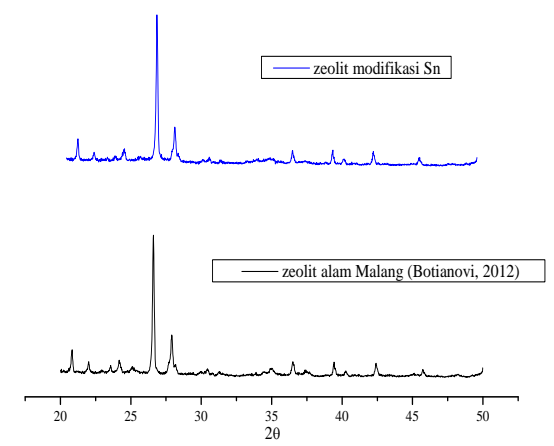

Gambar 6 Difraktogram hasil karakterisasi zeolit alam Malang dan zeolit alam Malang modifikasi $\mathrm{SnCl}_{2} \cdot 2 \mathrm{H}_{2} \mathrm{O} 0,24 \mathrm{M}$

Berdasarkan Gambar 6 hasil difraksi menggunakan X-Ray Difraktometer (XRD)-6000 3 kW Shimadzu dalam operasinya melibatkan radiasi $\mathrm{Cu}-\mathrm{K} \alpha$ pada $40 \mathrm{kV} 30 \mathrm{~mA}$. Zeolit alam Malang dan zeolit hasil modifikasi yang diukur pada sudut $2 \theta$ rentang $20^{\circ}-50^{\circ}$ menunjukkan pola difraksi dengan kristalinitas yang 
tinggi. Hal ini terlihat dari puncak atau peak yang tajam dan runcing pada zeolit alam dan zeolit modifikasi logam Sn konsentrasi 0,24 M. Dengan dilakukannya modifikasi penambahan logam Sn pada zeolit alam menunjukkan bahwa tidak terjadi perubahan struktur dan kristalinitas dari zeolit. Hal ini ditunjukkan dengan munculnya penampakan puncak khas zeolit alam Malang pada $2 \theta=20^{\circ}-30^{\circ}$ yang relatif sama antara zeolit alam dengan zeolit modifikasi.

Berikut hasil perubahan sudut $2 \theta$ antara zeolit alam dengan zeolit alam modifikasi logam Sn yang ditunjukkan pada Tabel 6

Tabel 6. Perbandingan sudut $2 \theta \quad 20-50^{\circ}$ zeolit alam dengan zeolit alam modifikasi

\begin{tabular}{|c|c|}
\hline $\begin{array}{l}\text { Sudut } 2 \theta \text { Zeolit } \\
\text { alam Malang } \\
\text { (Botianovi, } \\
\text { 2012) }\end{array}$ & $\begin{array}{l}\text { Sudut } 2 \theta \\
\text { Zeolit alam } \\
\text { Malang } \\
\text { modifikasi }\end{array}$ \\
\hline$; 22,00^{\circ}$ & $20,85^{\circ} ; 22,03$ \\
\hline 23, & ; $24,23^{\circ}$ \\
\hline $26,60^{\circ}$ & $26,62^{\circ} ; 27,92^{\circ}$ \\
\hline $30,44^{\circ}$ & $30,45^{\circ} ; 34,82^{\circ}$ \\
\hline $34,98^{\circ}$ & $36,51^{\circ} ; 37,38^{\circ}$ \\
\hline $37,44^{\circ}$ & $39,43^{\circ} ; 40,27^{\circ}$ \\
\hline $39,41^{\circ} ; 40,25^{\circ} ;$ & $42,41^{\circ}$; \\
\hline 42,4 & 45,77 \\
\hline $48,20^{\circ}$ & $48,12^{\circ}$; \\
\hline
\end{tabular}

Berdasarkan puncak pada sudut $2 \theta$ 20-50 ${ }^{\circ}$ antara zeolit alam malang dengan zeolit alam yang telah dimodifikasi logam $\mathrm{SnCl}_{2} \cdot 2 \mathrm{H}_{2} \mathrm{O} 0,24 \mathrm{M}$, menunjukkan bahwa terjadi pergeseran sudut $2 \theta$ yang tidak terlalu jauh antara zeolit alam dengan zeolit modifikasi. Pergeseran yang terjadi dikarenakan adanya perubahan fase setelah $\mathrm{Sn}$ diimpregnasikan pada zeolit alam. Hal ini menunjukkan bahwa logam $\mathrm{Sn}$ telah masuk ke dalam pori zeolit yang menyebabkan perubahan sudut $2 \theta$. Berdasarkan hasil analisis dengan XRD menggunakan standar JCPDS Power Diffraction File logam Sn diketahui sampel mempunyai puncak pada harga sudut $2 \theta$ yang berkesesuaian dengan logam $\mathrm{Sn}$ $\left(54,85^{\circ}\right)$ (Zhang., et.al, 2011).

\section{KESIMPULAN}

Hasil morfologi pemukaan katalis yang terbaik ditunjukkan pada penggunaan logam $\quad \mathrm{SnCl}_{2} \cdot 2 \mathrm{H}_{2} \mathrm{O} \quad 0,24 \quad \mathrm{M}$ yang diimpregnasikan pada pengemban. Nilai keasaman dari zeolit modifikasi hasil variasi konsentrasi $\mathrm{SnCl}_{2} \cdot 2 \mathrm{H}_{2} \mathrm{O}$ yang terbaik yaitu pada penggunaan logam $\mathrm{SnCl}_{2} \cdot 2 \mathrm{H}_{2} \mathrm{O} 0,24 \mathrm{M}$ adalah sebesar 0,4682 $\mathrm{mmol} / \mathrm{g}$. sedangkan luas permukaan spesifiknya adalah sebesar $2,268 \mathrm{~m}^{2} / \mathrm{g}$.

\section{DAFTAR PUSTAKA}

Botianovi, A. 2012. Modifikasi Zeolit Alam Malang dari mikropori ke Mesopori dengan Penambahan SurfaktanCTaBr (Cetyltrimethylammoniumbromide).

Skripsi Tidak Diterbitkan. Malang: Jurusan Kimia Fsaintek Universitas Islam Negeri Maulana Malik Ibrahim Malang.

Cardenas, G., Oliva, R., Reyes, P. 2002. Synthesis and Properties of $\mathrm{PdSn} / \mathrm{Al}_{2} \mathrm{O}_{3}$ and $\mathrm{PdSn} / \mathrm{SiO}_{2}$ Prepared by Solvated Metal Atom Dispersed Method. Journal of Moleculer Catalysis. Chile: Departamento de Polimeros.

Laniwati, Melia. 1999. Isomerisasi 1-buten Menggunakan Zeolit Alam asal Malang, Jawa Timur Sebagai Katalis. Skripsi Tidak Diterbitkan. Bandung: Jurusan Teknik Kimia Fakultas Teknologi Industri Institut Teknologi Bandung.

Maryani. 2010. Pengaruh Cara Pengembanan Logam Ni dan Mo Pada Zeolit Alam Aktif Terhadap Karakter Katalis Bimetal. Skripsi Tidak Diterbitkan. Surakarta: Jurusan Kimia FMIPA Universitas Sebelas Maret.

Moliner, M., Leshkov, Y., and Davis, M. E., 2010. Tin-Containing Zeolites Are Highly Active Catalysts For The Isomerization of Glucose In Water, PNAS Early Edition, 1-5. 
Muliasari, Evi. 2006. Pemanfaatan Zeolit Aktif Dari Turen Malang Untuk Pertukaran Ion Timbal (II). Skripsi Tidak Diterbitkan. Surabaya: Jurusan Kimia FMIPA Universitas Airlangga.

Rodiansono, Trisunaryanti, Triyono. 2007. Pengaruh Pengembanan Logam Ni dan $\mathrm{Nb}_{2} \mathrm{O}_{5}$ Pada Karakter Katalis Nizeolit dan Ni-Zeolit $\mathrm{Nb}_{2} \mathrm{O}_{5}$. Jurnal Sains dan Terapan Kimia Vol 1 (1) 20-28.

Sadiana, I.M., Falah, I.I., Triyono. 2001. Pembuatan Katalis Pt-Zeolit untuk Konversi n-Oktanol. Indonesian Jurnal of Chemistry. Vol 1 (2).

Savitri, N. D dan Veronica. 2010. Proses Produksi Dietil Eter dengan Dehidrasi Etanol pada Fase Cair. Skripsi Tidak Diterbitkan. Semarang: Jurusan Teknik Kimia Fakultas Teknik Universitas Diponegoro.

Setiadi dan Astri, P., 2007. Preparasi dan Karakterisasi Zeolit Alam Untuk
Konversi Senyawa Abe Menjadi Hidrokarbon. Prosiding Konggres dan Simposium Nasional Kedua MKICS ISSN: 0216-4183.

Suharto, T. E., Irfan G., Sundaryono, A., 2007, Pembuatan dan Karakterisasi Katalis Bifungsional dari Zeolit Alam, Jurnal Gradien Vol.3 No.2, 267-272.

Sundaryono, A., dan Budiyanto. 2008. Pembuatan Bahan Bakar Hidrokarbon Cair Melalui Reaksi Cracking Minyak Pada Limbah Cair Pengolahan Kelapa Sawit. Jurnal Teknoin Vol 20 (1) 14-19.

Zhang, G., Liu, N., Ren, Z., Yang, B. 2011. Synthesisof High Purity $\mathrm{SnO}_{2}$ Nanobeltsby Using Exothermic Reaction. Wuhan University: Department of Materials Engineering and Center for Electron Microscopy. 